\title{
Construction of productivity windows for fillet \\ welds using the FCAW process for thin ship panel \\ manufacturing
}

Construcción de ventanas de productividad de soldaduras en filete con proceso FCAW para la fabricación de paneles delgados de embarcaciones

DOI: https://doi.org/10.25043/19098642.176

Styvens Hernández Palacio ${ }^{1}$ Mateo Cardona Castaño ${ }^{2}$ Jorge E. Giraldo Barrada ${ }^{3}$

\begin{abstract}
The FCAW process used filler metal E71T-11 of $\varnothing 0.035$ ” to apply fillet welds with a size of $\sim 4 \mathrm{~mm}$ on T-joints made of ASTM A36 steel, in a horizontal position, using 42 appropriate combinations of wire feed speeds -WFS- (between 50 and $540 \mathrm{ipm}$ ), voltages (13-33V) and welding speeds (4.2-24.5 ipm). The test welds applied with each combination were inspected visually and by macro-attack to establish their compliance with the acceptance criteria for naval panels provided by the American Bureau of Shipping - ABS. With these results, Voltage vs. WFS, Voltage vs. Amperage and Heat Input vs. WFS graphs were constructed, and productivity windows were drawn over them including the combinations of welding parameters capable of producing welds of acceptable quality. The productivity windows obtained with this method, called ARCWISE, allow proper welding parameters to be selected during the design of WPSs avoiding iterative processes of trial and error.
\end{abstract}

Key words: Panel, FCAW, Productivity Windows, Arc length, Welding procedure (WPS), ABS.

\section{Resumen}

Se utilizó el proceso FCAW con electrodo E71T-11 de Ø0.035” para aplicar soldaduras en filete de tamaño $-4 \mathrm{~mm}$ sobre juntas en T de acero ASTM A36 en posición horizontal usando 42 combinaciones apropiadas de velocidades de alimentación de alambre -WFS- (entre 50-540 ipm), voltajes (13-33V) y velocidades de soldeo (4.2-24.5 ipm). Las soldaduras de prueba aplicadas con cada combinación se inspeccionaron visualmente y por macro-ataque para establecer su cumplimiento con los criterios de aceptación para paneles navales de la American Bureau of Shipping, ABS. Con los resultados se construyeron gráficos de Voltaje Vs WFS, Voltaje Vs Amperaje y Entrada de Energía Vs. WFS sobre los que se dibujaron ventanas de productividad con las combinaciones de parámetros capaces de producir soldaduras de calidad aceptable. Las ventanas de productividad construidas mediante este método, denominado ARCWISE, permiten seleccionar parámetros de soldeo durante el diseño de WPSs evitando procesos iterativos de ensayo y error.

Palabras claves: Panel, FCAW, Ventanas de Productividad, longitud de arco, procedimiento de soldadura (WPS), ABS.

Date Received: October $17^{\text {th }} 2018$ - Fecha de recepción: Octubre 17 de 2018

Date Accepted: December $20^{\text {th }} 2018$ - Fecha de aceptación: Diciembre 20 de 2018

\footnotetext{
${ }^{1}$ Universidad Nacional de Colombia. Medellín, Colombia. Email: shernandezp@unal.edu.co

${ }^{2}$ Universidad Nacional de Colombia. Medellín, Colombia. Email: macardonaca@unal.edu.co

${ }^{3}$ Universidad Nacional de Colombia. Medellín, Colombia. Email: jegirald@unal.edu.co
} 


\section{Introduction and justification}

An efficient design of steel or aluminum naval vessels aims, among other factors, to satisfy the criterion of reducing the weight of these structures by leveraging the advantages offered by the panels from the point of view of rigidity, moment of inertia and construction facilities. A structural panel can be described as a relatively thin plate with a network of stiffeners that increase their moment of inertia, rigidity and ability to withstand loads reducing the use of building materials (Blodgett, 1966). A panel can be flat (decks, tanks) or with a complex geometry (hulls, superstructures, bottoms or innerand-outer bottoms) and the stiffeners can be profiles of different cross sections such as angles, "Ts", "Is" or bulbs, which offers to the naval architects a wide variety of design alternatives for the construction of the various components of boats such as hulls, decks, bulkheads, bottoms, fuel, water and ballast storage tanks, etc. An initial phase of the construction of ships by means of the blocks assembly production method is the manufacture of panels consisting of, first, in making flat or curved plates using welded butt joints and, lastly, the assembly of the stiffeners in the plates with T-joints and joined using fillet welds (Boekholt, 2011).

One of the most common constructive problems with structures made with thin-plate steel or aluminum panels is associated with the angular distortion of the fillet welds used for the stiffenersplates connections (assembly of bulkheads, hulls and decks) which often results in local buckling and out-of-plane distortion which produces deflections and concavities in these structures (C.L. Tsai, 1999). The angular distortion inherent to the fillet welds produces an angular change as shown in Fig. 1 (Masubuchi, 1980) that can result, depending on the panel, in angular deflection or buckling of the panels as illustrated in the Fig. 2 (AWS, 1993).

There are several technical approaches to mitigate, or even solve, distortion problems that range from prevention at the design stage or during manufacturing, to the adoption of appropriate techniques to remove the distortion once it is present (C.L. Tsai, 1999), (Masubuchi, 1980), (ANSI/AWS D 3.5:93R, 1993) and (AISI/AWS D
3.7, 2004). Panel distortion control strategies can be grouped into: (1) design-related variables: use of design practices that facilitate the production of distortion-free panels, such as plates with the appropriate thickness, reduction of spacing between stiffeners, beveled T-joints, optimized assembly sequences, etc.; and (2) process-related variables: better control of certain welding variables that eliminate the conditions that promote distortion, such as the reduction of weld sizes and lengths, use of high welding speeds, the use of welding processes with low heat inputs, back-step techniques, proper welding sequences, controlled preheating, restriction fixturing, etc. (C.L. Tsai, 1999).

Fig. 1. Angular change due to angular distortion of the fillet welds (Masubuchi, 1980)

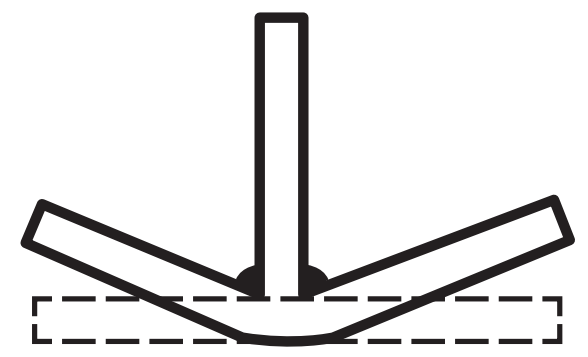

Fig. 2. Angular and buckling deflections due to the stiffeners welding of a panel-type structure (ANSI/AWS D 3.5:93R, 1993)
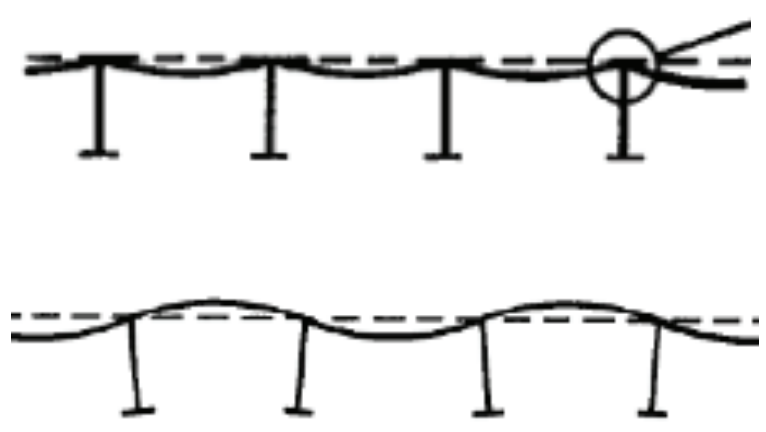

There are multiple research projects related with the distortion of panel-type structures in the naval industry and many prestigious researchers such as Masubuchi, Nakamura, Taniguchi, among others, have carried out research aimed at determining the magnitude of the angular change in T-joints 
with fillet welds as function of variables such as the material (aluminums or steels in general), the thickness of the plate and the electrode weight required for the unit length joint, which is a function of the size of the fillets. For low plate thicknesses of $9.5 \mathrm{~mm}(3 / 8 ")$ and thinner, a trend for the angular change to increase with the increase of the fillet weld size is noted (Fig. 3) and, consequently, with the heat input during the welding. This behavior is consistent with the recommendations available for the distortion control offered by different sources (C.L. Tsai, 1999), (Masubuchi, 1980) (ANSI/AWS D 3.5:93R, 1993) and (Miller, 2006) with respect to keeping the fillet size at the smallest possible values allowed by the production process.

However, there are certain limitations in the adoption of this measure that appears to be so simple: (1) first, there is a trend to over-weld, which may be the result from three different sources: the design engineer, when trying to be more conservative, can specify fillets larger than those required, then the welder tries to make welds with sizes larger than those specified in the drawings to avoid possible rejections, and finally a bad assembly of weldments with root openings higher than $1.6 \mathrm{~mm}$ requires the application of a larger fillet weld to meet the effective throat resulting in over-welding; (2) second, in general, there is no information about welding parameters suitable for making specific sizes of fillet welds (in particular the smallest with 3 to $4 \mathrm{~mm}$ that are equivalent to an effective throat of 2 and $3 \mathrm{~mm}$ ) and each welder uses a trial and error process in order to define their own parameters and try to accomplish your task. The importance of applying welds with an appropriate and consistent size is essential for implementing a distortion control plan because the application of welds larger than those needed will naturally result in more distortion and higher costs (Miller, 2006).

With these limitations in mind (the difficulty in obtaining small fillets in the panels avoiding over-welding and not having a robust database of welding parameters that allow to the manufacturers to obtain fillets in a consistent manner) it is advisable to take advantage of an experimental strategy developed in 1996 by the Edison Welding Institute called "ARCWISE" (Harwig, 2000). With this method an experimental series is carried out which consists of applying weld beads with an specific welding process under different parameters (amperage,

Fig. 3. Angular change on free fillet weds depending on the plate thickness and the weight of the electrode per unit of length (Masubuchi, 1980)

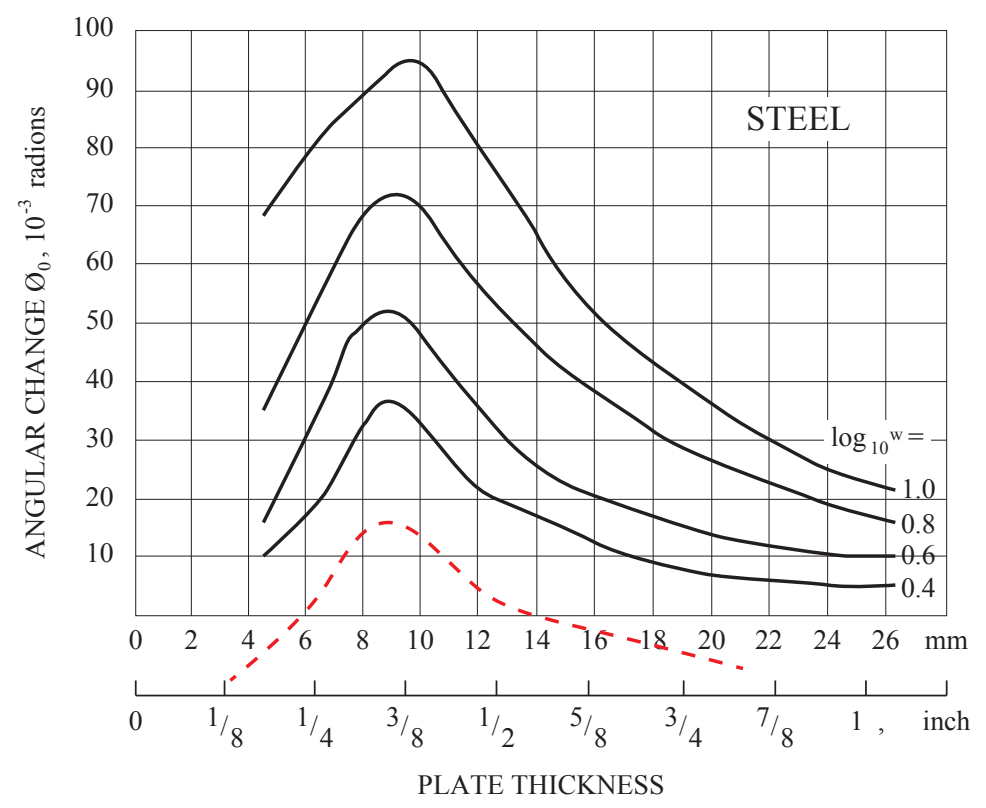


voltage, speed) in order to obtain a required weld (for example a fillet with a size of $5 \mathrm{~mm}$ ) under certain quality criteria (for example acceptance and rejection criteria given by a welding code for the defined fillet). The final result of the ARCWISE method is a set of graphs and productivity windows that serve as tools to select the different combinations of parameters for a welding process with which it is possible to obtain the desired weld by complying with preestablished quality criteria, without over-welding that increases distortion. With this systematic strategy is eliminated the frequently seen iterative approximation that consists of varying parameters such as voltage, amperage and speed, until the welding procedure values are found.

The objective of this paper is, therefore, to present the methodology and the results of the implementation of the ARCWISE strategy for the specific case of a small fillet weld $(4 \mathrm{~mm})$ that could be desirable to obtain consistently with the FCAW process for manufacturing thin panels of naval vessels with low thickness (approximately 5-6 mm). Following, each one of the steps of the ARCWISE methodology are explained in detail and the results of its application and the respective analysis of the results are included with the idea that it can be applied for different configurations found in the construction of naval building panels in order to reduce, in some degree, the impacts of angular distortion of the stiffeners of components such as decks, bulkheads and hulls. It should be clarified that the issue of distortions is a complex broad topic, and one whose solution requires multiple inter-related working fronts, one of which is shown in this paper. The present information may not be considered, in any case whatsoever, as being sufficient to avoid the distortion troubles.

\section{Experimental methodology}

The methodology followed in this work is based on the experimental strategy known as "ARCWISE", which is based on a volume (or mass) balance between the input of filler material delivered by a welding process (GMAW, FCAW, SAW) applied under specific parameters and the material that is actually deposited in the weldment. The volumetric flow of the process is equal to the volumetric flow of the applied weld. The effectiveness of the method is based on that in order to keep constant the welding area using different parameters, is required that the relationship between the wire feed speed (WFS) of a process and the welding travel speed (TS) must be constant, as is explained in the Test matrix with constant deposit area. In other words, if the WFS/ TS relationship is kept constant, then the cross section area of the weld will remain the same. The steps or stages of the ARCWISE methodology are as follows:

- Definition of the "application" (type and size of the weld and acceptance and rejection criteria).

- Construction of a test matrix with constant deposit area.

- Application of test welds with a constant arc length.

- Weld profile measurements.

- Construction of the operative windows and productivity windows.

The ARCWISE methodology is explained in detail below, step by step, using a real and concrete example interesting for the manufacture of thin panels in the naval industry.

\section{Application of the ARCWISE method, results and analysis}

\section{Definition of the application}

The application is defined as the set of design factors (base material, thicknesses, type of joint, type and size of weld, profile of the bead, position) and the respective acceptance and rejection criteria that are normally based on an applicable welding code.

For our example we took a T-joint of ASTM A36 steel plates with a thickness of $4.8 \mathrm{~mm}(3 / 16 ")$ joined by a fillet weld with a leg size $5 / 32 "(-4 \mathrm{~mm})$ in horizontal position $(2 \mathrm{~F})$ as illustrated in Figures 4 (A), (B) and (C).

The rules for the classification of naval vessels according to the American Bureau of Shipping (ABS) were used to define the acceptance and rejection criteria. The Rules for Materials and 
Welds Part 2 of ABS (ABS, 2016), establish in Chapter 4 "Welding and Fabrication", Section 1 "Hull Construction", paragraph 5.17 "Inspection of Welds" that the inspected welds must be evaluated according to the acceptance criteria given in the ABS Guide for the Nondestructive Inspection of Hull Welds (ABS, 2018) which, in its paragraph 1.3 "Visual Inspection of Welds" establishes that the acceptance criteria are indicated in the Section 10 "Acceptance Criteria For Hull Welds" paragraph 5 "Evaluation from Visual Inspection (VT), Magnetic Inspection (MT) and Liquid Penetrant Inspection (PT)." This ABS guide also establishes in section 1.1 that the surface appearance of the welds during the construction of hulls must meet the requirements of recommendation No. 47 of the IACS (IACS, 2012). The criteria applicable to fillet welds according to the ABS and the AIACS are summarized in Table 1.

Table 1. Acceptance criteria for non-primary members for vessels

\begin{tabular}{|c|c|c|}
\hline $\begin{array}{c}\text { FEATURE OR } \\
\text { DEFECT }\end{array}$ & $\begin{array}{l}\text { MINIMUM } \\
\text { VALUE }\end{array}$ & $\begin{array}{l}\text { MAXIMUM } \\
\text { VALUE }\end{array}$ \\
\hline Porosity diameter & $0 \mathrm{~mm}$ & $<1 \mathrm{~mm}$ \\
\hline $\begin{array}{l}\text { Undercut (all the } \\
\text { length) }\end{array}$ & $0 \mathrm{~mm}$ & $\leq 0.5 \mathrm{~mm}$ \\
\hline $\begin{array}{l}\text { Undercut (Max. } 90 \\
\text { mm) }\end{array}$ & $0 \mathrm{~mm}$ & $\leq 0.8 \mathrm{~mm}$ \\
\hline Reinforcement & 0 & $\leq 2 \mathrm{~mm}$ \\
\hline Root penetration & $\geq 0$ & \\
\hline Cracks & 0 & 0 \\
\hline Lack of fusion & 0 & 0 \\
\hline Overlap & 0 & 0 \\
\hline
\end{tabular}

Plates of ASTM A36 steel with 3/16" (4.8 mm) assembled in T-Joints were used for the test coupons. FCAW process was used to apply the welds with a $\varnothing 0.035 "(\varnothing 0.9 \mathrm{~mm})$ Lincoln self-shielded electrode NR-211-MP which meets the standard AWS A5.20 Class E71T-11, CDEN, contact tip to work distance of 13-14 mm, horizontal position (2F) and working angle of $45^{\circ}$. A constant voltage power source Miller Invision 456MP and a Miller feeder S-74D with the gun installed in a Bug-O welding automated system were used. The Figure 4 illustrates the equipment used for the application of welds in mechanized mode and the arrangement of coupons.
Testing matrix with constant deposit area

In this stage of the ARCWISE methodology a matrix of welding tests is created that consists of defining the number of weld test and the welding parameters of each bead (wire feed speed -WFS-, voltage $\mathrm{V}$, arc length - LA- and travel speed of welds -TS-) calculated in order to obtain always a constant deposit area-DA-, i.e. welds with the same cross section.

Fig. 4. Equipment used to apply test welds in horizontal position $(2 \mathrm{~F})$

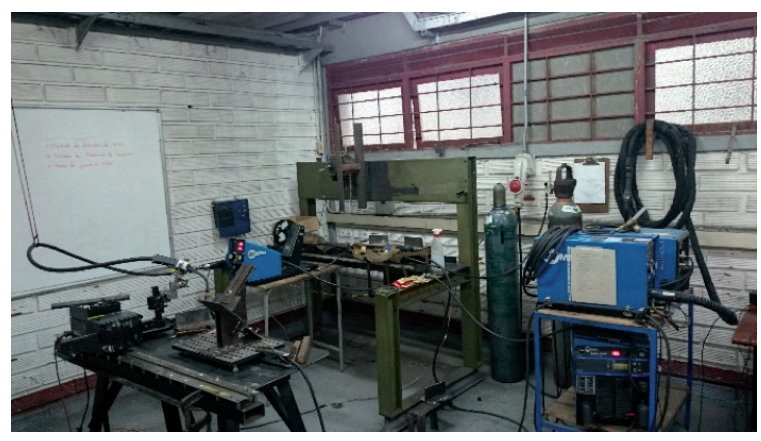

(A) General equipment arrangement

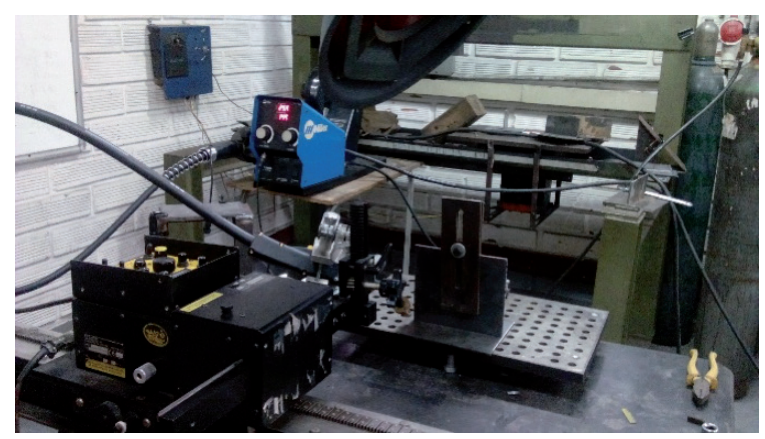

(B) Bug-O automated equipment and test coupon

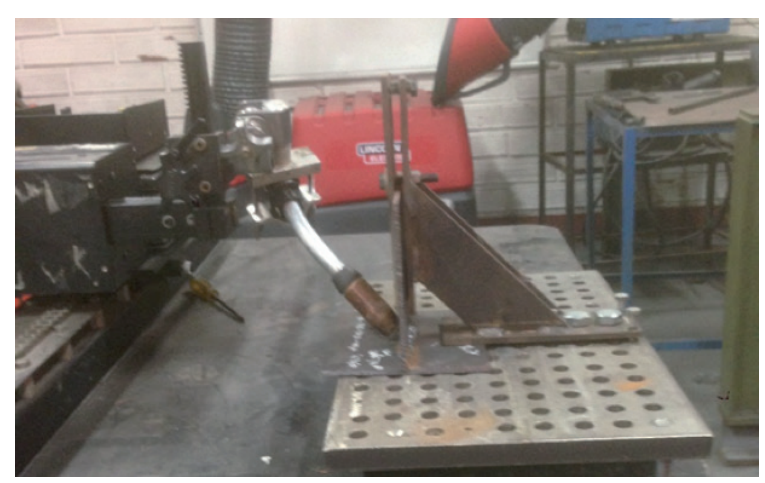

(C) Pistol and coupon arrangement in $2 \mathrm{f}$ 
The basis for the construction of the matrix is therefore the area of the cross section of the weld defined in the application that, for our case, is a fillet with a $5 / 32 "(-4 \mathrm{~mm})$ leg, whose area is calculated as $D A=b^{*} b / 2=4^{*} 4 / 2=8 \mathrm{~mm}^{2}$. This theoretical area should be increased by a reinforcement factor, r, with approximately $20 \%$ that represents the convexity of the fillet weld.

Constant deposit area tests are based, as already stated, on a volume or mass balance between the material delivered by the process (that is a function of the wire feed speed -WFS-, the cross section area of the filler metal $-A W$ - and the deposition efficiency of the welding process $-\eta_{d}$ - assumed to be equal to 0.8 for $F C A W$ ) and the material that is actually deposited on the weldment (which is function of $D A, \mathrm{r}$ and the welding speed $-T S_{-}-$). With this volume balance it is possible to find a dimensionless ratio between the wire feed speed WFS and welding speed TS that will always have a constant value for the same application, as shown below:

$$
\begin{aligned}
& D A \times T S \times r=W F S \times A_{W} \times \eta_{d} \\
& \therefore \quad \frac{W F S}{T S}=\frac{(D A \times r)}{\left(A_{W} \times \eta_{d}\right)}
\end{aligned}
$$

That for our application will be:

$$
\begin{aligned}
& \frac{W F S}{T S}=\frac{\left(\frac{4 x 4}{2} \times 1.2\right)}{\left(\frac{\pi x 0.89}{4} \times 0.8\right)} \approx 19.29 \\
& \frac{W F S}{T S}=19.29
\end{aligned}
$$

Maintaining this value of WFS/TS $\approx 19.3$ the different values of WFS are found as a function of the application speeds of typical welds for the $F C A W$ process in manual mode that can be in the range of $5 \mathrm{ipm}(2.1 \mathrm{~mm} / \mathrm{s})$ and $30 \mathrm{ipm}(12.7 \mathrm{~mm} / \mathrm{s})$. The WFS variation was established from $50 \mathrm{ipm}$ up to about $500 \mathrm{ipm}$ with increments of $30 \mathrm{ipm}$; then, the corresponding $T S$ values were calculated

\begin{tabular}{|c|c|c|c|}
\hline $\begin{array}{l}\text { Length of the } \\
\text { arc }(\mathrm{mm})\end{array}$ & $\begin{array}{c}\text { Wire feed } \\
\text { speed (ipm) }\end{array}$ & $\begin{array}{c}\text { Voltage } \\
\text { (V) }\end{array}$ & $\begin{array}{c}\text { Welding } \\
\text { speed (ipm) }\end{array}$ \\
\hline \multirow{13}{*}{-1} & 80 & 13.0 & 4.2 \\
\hline & 110 & 13.5 & 5.7 \\
\hline & 140 & 15.0 & 7.3 \\
\hline & 170 & 18.0 & 8.9 \\
\hline & 200 & 19.0 & 10.4 \\
\hline & 230 & 20.3 & 12.0 \\
\hline & 260 & 20.3 & 13.5 \\
\hline & 290 & 20.3 & 15.1 \\
\hline & 320 & 20.8 & 16.7 \\
\hline & 350 & 20.8 & 18.2 \\
\hline & 380 & 20.8 & 19.8 \\
\hline & 410 & 21.0 & 21.4 \\
\hline & 440 & 21.0 & 22.9 \\
\hline \multirow{18}{*}{3} & 50 & 14.3 & 2.6 \\
\hline & 80 & 16.0 & 4.2 \\
\hline & 110 & 18.0 & 5.7 \\
\hline & 140 & 20.2 & 7.3 \\
\hline & 170 & 22.0 & 8.9 \\
\hline & 200 & 22.0 & 10.4 \\
\hline & 230 & 22.0 & 12.0 \\
\hline & 260 & 22.5 & 13.5 \\
\hline & 290 & 23.0 & 15.1 \\
\hline & 320 & 23.8 & 16.7 \\
\hline & 350 & 23.1 & 18.2 \\
\hline & 380 & 24.5 & 19.8 \\
\hline & 410 & 25.3 & 21.4 \\
\hline & 440 & 26.1 & 22.9 \\
\hline & 470 & 26.6 & 24.5 \\
\hline & 500 & 29.7 & 26.0 \\
\hline & 530 & 30.0 & 27.6 \\
\hline & 560 & 30.3 & 29.2 \\
\hline \multirow{7}{*}{5} & 170 & 26.6 & 8.9 \\
\hline & 200 & 27.0 & 10.4 \\
\hline & 230 & 27.1 & 12.0 \\
\hline & 260 & 27.5 & 13.5 \\
\hline & 290 & 28.6 & 15.1 \\
\hline & 320 & 29.5 & 16.7 \\
\hline & 350 & 29.8 & 18.2 \\
\hline
\end{tabular}
to construct the matrix shown in Table 2 .
Table 2. Matrix of application parameters for test welds with constant deposit area 


\begin{tabular}{|c|c|c|c|}
\hline \multirow{4}{*}{5} & 380 & 30.1 & 19.8 \\
\hline & 410 & 31.8 & 21.4 \\
\hline & 440 & 33.1 & 22.9 \\
\hline & 470 & 33.1 & 24.5 \\
\hline
\end{tabular}

Units of the English system were used as the welding equipment adjustments employ this system. The voltage and arc length values indicated in Table 2 are explained in the following paragraph. It is noted that the WFS/TS ratio of each test weld is $\approx 19.3$.

Thus, the welding parameters were defined to experimentally apply 42 test fillet welds with constant deposit area according to the application defined in this study. To improve the validity of the results, other 42 replica welds were applied in the study. With these 42 welds most of the productive spectrum of the FCAW process is covered to obtain consistently this specific fillet weld (or application) with the class and diameter of the electrode used and in the $2 \mathrm{~F}$ position.

\section{Application of welding tests with constant arc length}

The ARCWISE methodology requires that the welds be applied with a relatively constant arc length $(L A)$. The LA is approximately proportional to the arc voltage so it gives an indication of its level. On this study were used three levels of arc length: (1) $L A \approx 5 \mathrm{~mm}$ that is presented in high arc voltages between 27 and $33 \mathrm{~V}$; (2) $L A \approx 3 \mathrm{~mm}$ that is presented in voltages between 14 and $30 \mathrm{~V}$; and (3) $L A$ approximately $1 \mathrm{~mm}$ (an arc that is almost flush with the weld puddle having a height close to $1 \mathrm{~mm}$ ) which is produced at the lowest voltages between 13 and 21V (See Table 2).

To establish the $L A$, pictures of the welding arc were taken for each $W F S$ varying the voltage to get required $L A(-1,3$ and $5 \mathrm{~mm})$. A DSLR Canon Rebel T3i camera was used with an EF 75-300mm telephoto lens with UV filter and mounted on 50" tripod at an approximate distance of $1.6 \mathrm{~m}$. To achieve a good contrast of the arc and the electrode tip, the pictures were taken at a speed of $1 / 500$ s, with diaphragm aperture of $f 22$ in burst mode and with the lights of the laboratory switched off. Fig. 5 illustrates the layout of the Camera and the weld coupon. The voltages obtained for each WFS and $L A$ are included in Table 2.

Fig. 5. Layout for the photographic record required for measuring the arc length

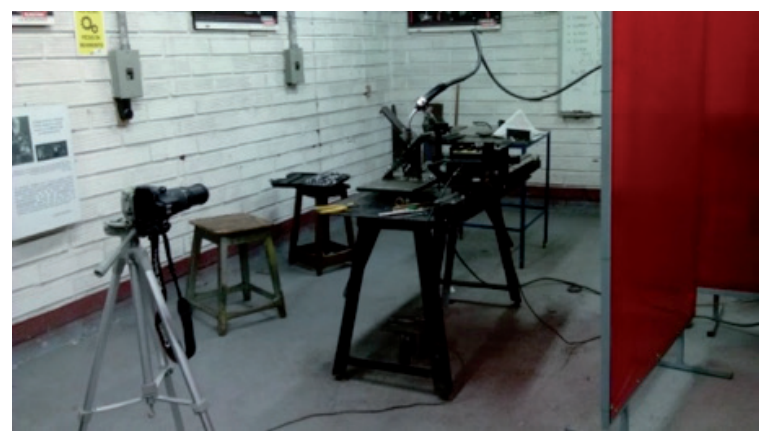

Fig. 6 shows arc pictures of three test welds processed in SOLIDWORKS with the preselected $L A$ measurements calculated taking as reference the contact tube diameter and/or the electrode diameter.

Fig. 6. Pictures and measurements of the arc length. Software used: SOLID WORKS

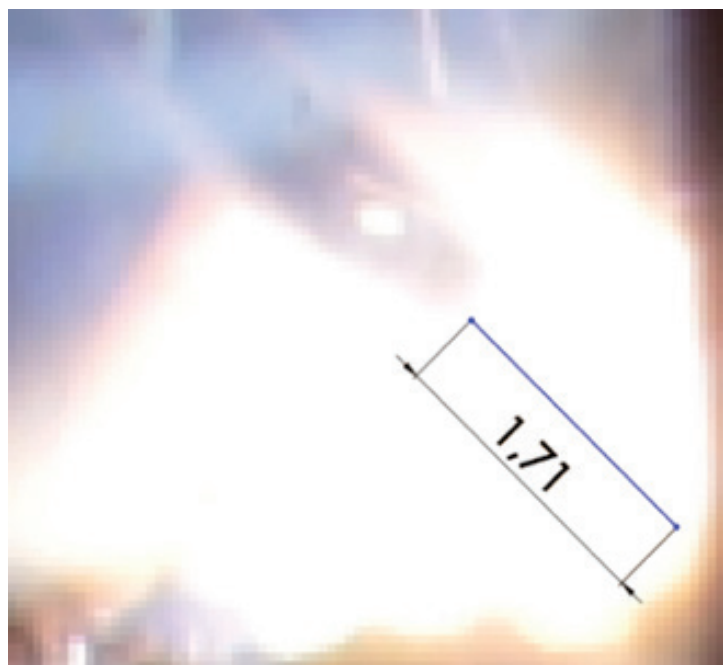

a) Arc length with approximately $1 \mathrm{~mm}$. 


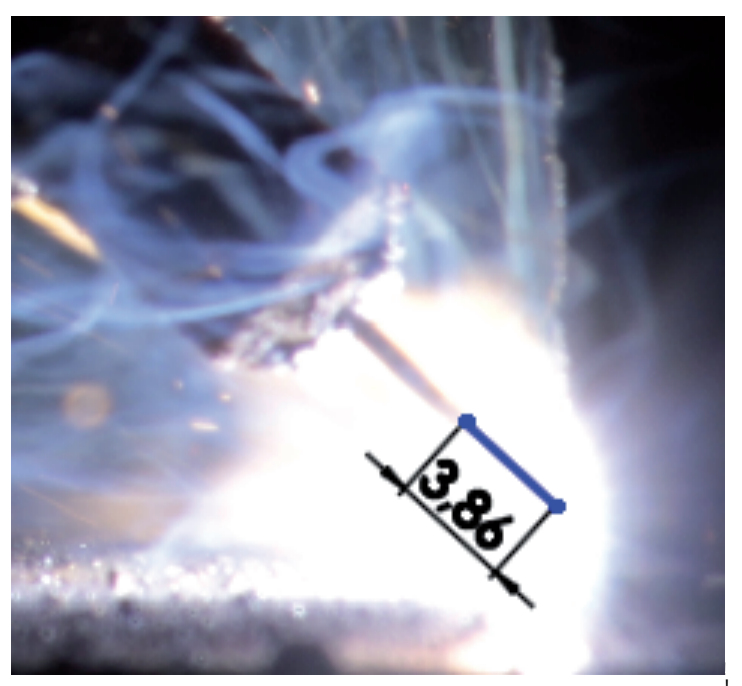

b) Arc length with approximately $3 \mathrm{~mm}$.

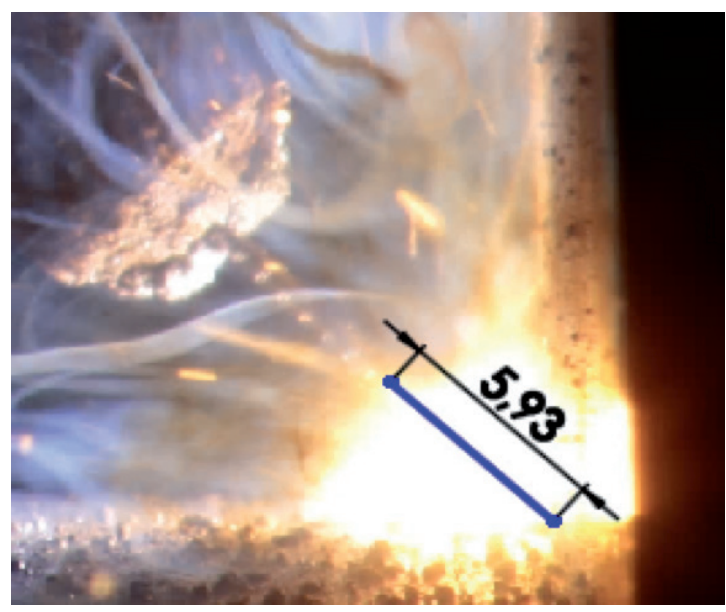

c) Arc length with approximately $5 \mathrm{~mm}$.

With the information indicated in Table 2, the test welds on ASTM A36 steel coupons were applied and replica coupons were also welded for each combination of parameters.

\section{Dimensions, shape and profile of the weld measurements}

At this stage of the ARCWISE methodology the welded coupons were visually inspected using typical welding gauges for measuring attributes such as the fillet size, undercutting, concavity, convexity, overlap, cracks, etc., that allowed to evaluated whether the criteria of acceptance established for the application was met. The results of the visual inspection for the test fillet welds and the evaluation are presented in Table 3.

From the results it can be calculated that the average area of the weld beads is $8.3 \mathrm{~mm} 2 \pm 1.3$ $\mathrm{mm}^{2}$, which is very close to the $D A$ area of the fillet considered in the application. The differences can be due to the level of process efficiency $\eta_{d}=0.8$ which is a theoretical value and not a measured value. For future jobs it would be better to measure the process deposition efficiency for various WFSs in order to achieve a better match with the weld areas. The average size of the fillets also stayed at a value close to $3.7 \mathrm{~mm}$ regardless the change in arc power $\left(P=V^{*} I\right)$ caused by variations in the arc length and the WFSs.

Subsequently, each test coupon was cut into two cross sections, as illustrated in Fig. 7, in order to polish the welds using abrasive cloths with particle size \#100 to \#400 and attack them with the reagent NITAL 5 (95\% ethyl alcohol + 5\% $\mathrm{HNO}_{3}$ ) to reveal their macro-structure and take macro-photographs in a stereoscopic microscope. The pictures of each section (two per coupon) were processed in SOLIDWORKS to estimate the dimensions of legs, undercuts, convexity, penetration, the presence of welding defects such as undercuts, lack of fusion, lack of penetration, etc., and evaluate whether they met the acceptance criteria for the application.

Fig. 7. Weld test coupon WFS $=470 \mathrm{ipm}$ and $\mathrm{LA}=3 \mathrm{~mm}$ sectioned for the macro-examination

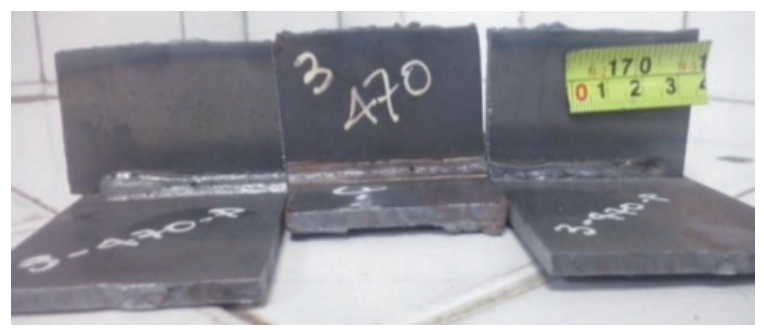

Fig. 8 (A) presents the macro-photograph of the welding applied with $W F S=320 \mathrm{ipm}, L A=3 \mathrm{~mm}$ and $23.8 \mathrm{~V}$ (left fillet) and that of its replica (right fillet), respectively. Fig. 8 (B) shows the image processed in SOLIDWORKS with the fillet estimated dimensions. 
Table 3. Results of visual inspection of welds and evaluation against the criteria provided by the American Bureau of Shipping -ABS

\begin{tabular}{|c|c|c|c|c|c|c|c|c|c|}
\hline $\begin{array}{l}\text { WELD TEST } \\
\text { DESIGNA TION } \\
\text { (LA-WFS-V) }\end{array}$ & 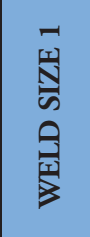 & 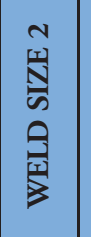 & 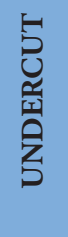 & 永 & 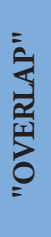 & 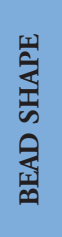 & 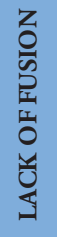 & 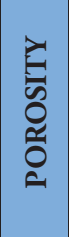 & 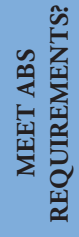 \\
\hline $1-80-13.0$ & 0.0 & 0.0 & 0.0 & $\mathrm{~N}$ & $\mathrm{Y}$ & $\mathrm{EC}$ & $\mathrm{Y}$ & $\mathrm{N}$ & NO \\
\hline $1-110-13.5$ & 4.1 & 2.9 & 0.0 & $\mathrm{~N}$ & $\mathrm{Y}$ & $\mathrm{EC}$ & $\mathrm{Y}$ & $\mathrm{N}$ & NO \\
\hline $1-140-15.0$ & 3.5 & 1.9 & 0.0 & $\mathrm{~N}$ & $\mathrm{Y}$ & $\mathrm{EC}$ & $\mathrm{N}$ & $\mathrm{N}$ & NO \\
\hline $1-170-18.0$ & 3.7 & 3.5 & 0.0 & $\mathrm{~N}$ & $\mathrm{~N}$ & $\mathrm{~F}$ & $\mathrm{~N}$ & $\mathrm{~N}$ & YES \\
\hline $1-200-19.0$ & 3.5 & 3.5 & 0.0 & $\mathrm{~N}$ & $\mathrm{~N}$ & $\mathrm{~F}$ & $\mathrm{~N}$ & $\mathrm{~N}$ & YES \\
\hline $1-230-20.3$ & 3.8 & 3.5 & 0.0 & $\mathrm{~N}$ & $\mathrm{~N}$ & $\mathrm{C}$ & $\mathrm{N}$ & $\mathrm{N}$ & YES \\
\hline $1-260-20.3$ & 3.6 & 4.3 & 0.0 & $\mathrm{~N}$ & $\mathrm{~N}$ & C & $\mathrm{N}$ & 0.6 & YES \\
\hline $1-290-20.3$ & 3.5 & 3.8 & 0.0 & $\mathrm{~N}$ & $\mathrm{~N}$ & $\mathrm{~F}$ & $\mathrm{~N}$ & 0.5 & YES \\
\hline $1-320-20.8$ & 3.5 & 4.0 & 0.0 & $\mathrm{~N}$ & $\mathrm{~N}$ & $\mathrm{~F}$ & $\mathrm{~N}$ & $\mathrm{~N}$ & YES \\
\hline $1-350-20.8$ & 3.8 & 3.7 & 0.0 & $\mathrm{~N}$ & $\mathrm{~N}$ & $\mathrm{~F}$ & $\mathrm{~N}$ & $\mathrm{~N}$ & YES \\
\hline $1-380-20.8$ & 3.7 & 3.8 & 0.0 & $\mathrm{~N}$ & $\mathrm{~N}$ & $\mathrm{C}$ & $\mathrm{N}$ & $\mathrm{N}$ & YES \\
\hline $1-410-21.0$ & 3.5 & 3.3 & 0.0 & $\mathrm{~N}$ & $\mathrm{Y}$ & $\mathrm{C}$ & $\mathrm{N}$ & $\mathrm{N}$ & $\mathrm{NO}$ \\
\hline $1-440-21.0$ & 3.6 & 2.3 & 0.0 & $\mathrm{~N}$ & $\mathrm{~N}$ & $\mathrm{C}$ & $\mathrm{N}$ & $\mathrm{N}$ & NO \\
\hline $3-50-14.3$ & \multicolumn{8}{|c|}{ COMPLETELY IRREGULAR BEAD } & NO \\
\hline $3-80-16.0$ & 2.3 & \begin{tabular}{|l|l}
4.0 \\
\end{tabular} & \multicolumn{6}{|c|}{ IRREGULAR BEAD } & NO \\
\hline 3-110-180.0 & 3.0 & 3.3 & 0.0 & $\mathrm{~N}$ & $\mathrm{~N}$ & $\mathrm{C}$ & $\mathrm{N}$ & $\mathrm{N}$ & NO \\
\hline $3-140-20.2$ & 3.6 & 4.5 & 0.0 & $\mathrm{~N}$ & $\mathrm{~N}$ & $\mathrm{~F}$ & $\mathrm{~N}$ & PT & YES \\
\hline $3-170-22.0$ & 3.7 & 4.3 & 0.0 & $\mathrm{~N}$ & $\mathrm{~N}$ & $\mathrm{~F}$ & $\mathrm{~N}$ & $\mathrm{~N}$ & YES \\
\hline $3-200-22.0$ & 4.2 & 3.6 & 0.0 & $\mathrm{~N}$ & $\mathrm{~N}$ & $\mathrm{C}$ & $\mathrm{N}$ & $\mathrm{N}$ & YES \\
\hline $3-230-22.0$ & 3.6 & 3.7 & 0.0 & $\mathrm{~N}$ & $\mathrm{~N}$ & $\mathrm{~F}$ & $\mathrm{~N}$ & 0.5 & YES \\
\hline $3-260-22.5$ & 3.7 & 4.3 & 0.0 & $\mathrm{~N}$ & $\mathrm{~N}$ & $\mathrm{~F}$ & $\mathrm{~N}$ & 0.6 & YES \\
\hline 3-290-23.0 & 4.1 & 3.7 & 0.0 & $\mathrm{~N}$ & $\mathrm{~N}$ & $\mathrm{~F}$ & $\mathrm{~N}$ & 0.7 & YES \\
\hline 3-320-23.8 & 3.9 & 3.5 & 0.0 & $\mathrm{~N}$ & $\mathrm{~N}$ & $\mathrm{~F}$ & $\mathrm{~N}$ & 0.8 & YES \\
\hline $3-350-23.1$ & 4.2 & 3.7 & 0.0 & $\mathrm{~N}$ & $\mathrm{~N}$ & $\mathrm{~F}$ & $\mathrm{~N}$ & 1.3 & YES \\
\hline $3-380-24.5$ & 4.2 & 3.6 & 0.0 & $\mathrm{~N}$ & $\mathrm{~N}$ & $\mathrm{C}$ & $\mathrm{N}$ & 0.9 & YES \\
\hline $3-410-25.3$ & 4.1 & 4.3 & 0.0 & $\mathrm{~N}$ & $\mathrm{~N}$ & $\mathrm{C}$ & $\mathrm{N}$ & $\mathrm{N}$ & YES \\
\hline $3-440-26.1$ & 3.8 & 3.5 & 0.0 & $\mathrm{~N}$ & $\mathrm{~N}$ & $\mathrm{C}$ & $\mathrm{N}$ & 1.0 & YES \\
\hline $3-470-26.6$ & 4.1 & 3.9 & 0.0 & $\mathrm{~N}$ & $\mathrm{~N}$ & $\mathrm{C}$ & $\mathrm{N}$ & 0.8 & YES \\
\hline $3-500-29.7$ & 3.7 & 2.1 & 1.2 & $\mathrm{~N}$ & $\mathrm{Y}$ & $\mathrm{C}$ & $\mathrm{N}$ & 0.9 & NO \\
\hline $3-530-30.0$ & 3.3 & 3.6 & 1.4 & $\mathrm{~N}$ & $\mathrm{~N}$ & $\mathrm{EC}$ & $\mathrm{N}$ & $\mathrm{PT}$ & NO \\
\hline $3-560-30.3$ & \multicolumn{2}{|c|}{ IRREGULAR } & 1.4 & $\mathrm{~N}$ & $\mathrm{Y}$ & $\mathrm{C}$ & $\mathrm{N}$ & PT & NO \\
\hline $5-170-26.6$ & 3.3 & 3.5 & 1.2 & $\mathrm{~N}$ & $\mathrm{~N}$ & $\mathrm{~F}$ & $\mathrm{~N}$ & $\mathrm{~N}$ & NO \\
\hline $5-200-27.0$ & 3.8 & 3.9 & 1.1 & $\mathrm{~N}$ & $\mathrm{~N}$ & $\mathrm{~F}$ & $\mathrm{~N}$ & 0.6 & NO \\
\hline $5-230-27.1$ & 3.6 & 4.2 & 0.8 & $\mathrm{~N}$ & $\mathrm{~N}$ & $\mathrm{~F}$ & $\mathrm{~N}$ & $\mathrm{~N}$ & YES \\
\hline $5-260-27.5$ & 3.8 & 3.9 & 0.8 & $\mathrm{~N}$ & $\mathrm{~N}$ & $\mathrm{C}$ & $\mathrm{N}$ & 0.9 & YES \\
\hline 5-290-28.6 & 4.3 & 3.6 & 1.2 & $\mathrm{~N}$ & $\mathrm{~N}$ & $\mathrm{C}$ & $\mathrm{N}$ & 1.0 & NO \\
\hline 5-320-29.5 & 3.8 & 3.7 & 1.0 & $\mathrm{~N}$ & $\mathrm{Y}$ & $\mathrm{C}$ & $\mathrm{N}$ & 2.5 & NO \\
\hline $5-350-29.8$ & 4.1 & 4.4 & 1.6 & $\mathrm{~N}$ & $\mathrm{~N}$ & $\mathrm{C}$ & $\mathrm{N}$ & $\mathrm{N}$ & NO \\
\hline 5-380-30.1 & 3.5 & 4.5 & 1.8 & $\mathrm{~N}$ & $\mathrm{~N}$ & $\mathrm{C}$ & $\mathrm{N}$ & 1.4 & NO \\
\hline $5-410-31.8$ & 3.8 & 3.9 & 0.0 & $\mathrm{~N}$ & $\mathrm{~N}$ & $\mathrm{C}$ & $\mathrm{N}$ & $\mathrm{N}$ & NO \\
\hline 5-440-33.1 & 3.3 & 4.2 & 1.4 & $\mathrm{~N}$ & $\mathrm{~N}$ & $\mathrm{C}$ & $\mathrm{N}$ & 0.5 & NO \\
\hline $5-470-33.1$ & \multicolumn{2}{|c|}{ IRREGULAR } & 2.0 & $\mathrm{~N}$ & $\mathrm{Y}$ & $\mathrm{EC}$ & $\mathrm{N}$ & $\mathrm{N}$ & NO \\
\hline
\end{tabular}

\begin{tabular}{|c|c|}
\hline $\mathbf{N}$ & NO \\
\hline $\mathbf{Y}$ & YES \\
\hline $\mathbf{F}$ & Flat bead contorn \\
\hline $\mathbf{C}$ & Convex bead contorn \\
\hline EC & Excesive convexity \\
\hline PT & Piping porosity \\
\hline & Meet Requirements \\
\hline & No meet requirements \\
\hline & \\
\hline LA & Arc Length \\
\hline WFS & Wire Feed Speed \\
\hline V & Voltage \\
\hline
\end{tabular}


Fig. 8. Macro-photography of welding applied with WFS= $320 \mathrm{ipm}$ and $\mathrm{LA}=3 \mathrm{~mm}$

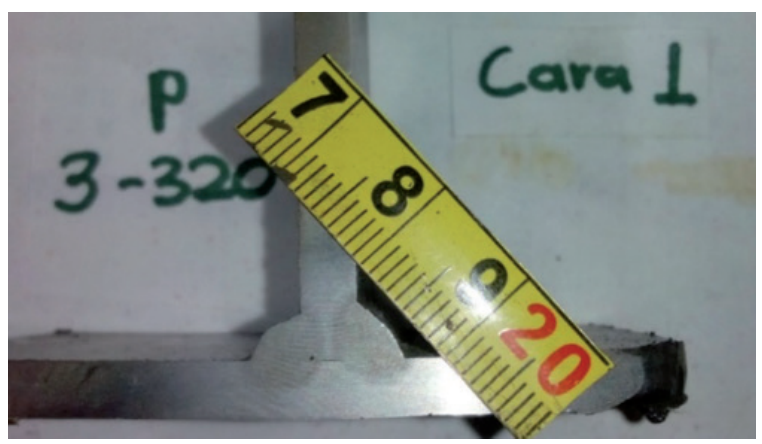

(A) Macro-photography of the weld and replica

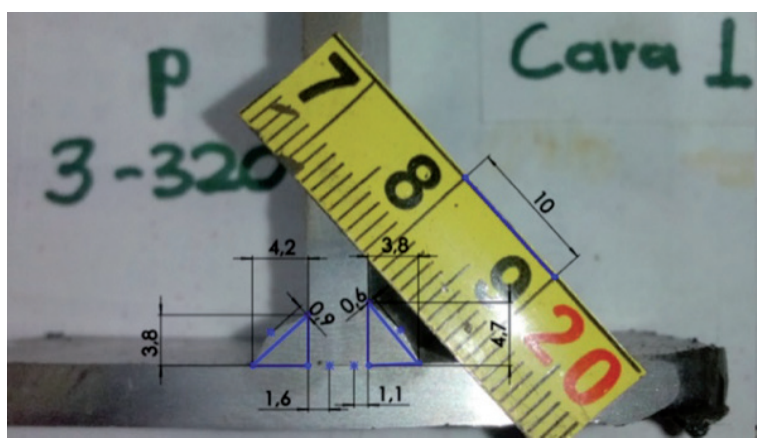

(B) Picture processed in SOLIDWORKS

Fig. 9 includes a chart with a collection of representative macro-photographs covering a wide range of the spectrum of test welds from this study between $W F S=110 \mathrm{ipm}$ to $470 \mathrm{ipm}$, for the three arc lengths. Framed with a solid green color border are shown the welds that have been evaluated as "acceptable" according to the acceptance criteria of the ABS-Guide for Nondestructive Inspection of Hull Welds, both for visual inspection and macroexamination. It is noted that with the lowest power levels, i.e. at low voltages and amperages (or WFS), and low welding speeds, the welds exhibit overlaps, excessive convexity, lack of fusion between the weld metal and base metal, low dilution and lack of penetration in the root of the join. At low WFSs and higher voltages the electric arc was extremely unstable and the welds obtained were very nonuniform and discontinuous, so these welds do not were examined by macro-attack. The deepest undercuts are seen at the higher voltages (high arc lengths), being higher when amperage (WFS) and the welding speed become greater; this is because the electric arc is wider and directly impacts the base metal. It can be seen that the penetration and dilution of the welds increases with the increase of the arc power $\left(P=V^{*} I\right)$, i.e. at higher voltages $(L A)$ and amperages (WFS), since it is well known that the increase in power and the welding speed increases the melting efficiency of the process (Kou, 2002). At the highest wire feed speeds and low voltages $(L A \approx 1 \mathrm{~mm})$, a phenomenon called "stubbing" occurred which consists in that the tip of the solid electrode strikes against the base metal without an adequate metal transfer, which produces discontinuous and bad quality welds.

The results of visual inspection and macro-attack examination serve to define productivity windows or sets of welding parameters in order to obtain fillet welds that met both application and predefined acceptance criteria.

It is important to see that most of the welds applied with the average arc length $(L A \approx 3 \mathrm{~mm})$ were acceptable in quality, same as those of lower arc voltages, except for the lower amperage levels below 100A. At very high voltages the acceptance rate was substantially reduced.

\section{Construction of graphs and productivity windows}

In the final stage of the ARCWISE method the productivity or operative windows are built that can be graphs of Voltage vs. WFS or Voltage vs. Current which include the points of the combination of parameters used for each weld, the welding speed lines and the union of the points of those welds evaluated as acceptable in order to draw on the charts the regions of fulfillment of the quality criteria. This window contains the set of welding parameters that enable to obtain the desired weld or application satisfactorily. Figs. 10 and 11 includes the graphs of Voltage vs. WFS and Voltage vs. Amperage, respectively, for the application defined for this work, in addition to the respective productivity windows (shaded) constructed after evaluating the results of the visual inspection and macro-examination. 
Fig. 9. Photo-ultrasounds with the shape of the welding beads according to the welding parameters

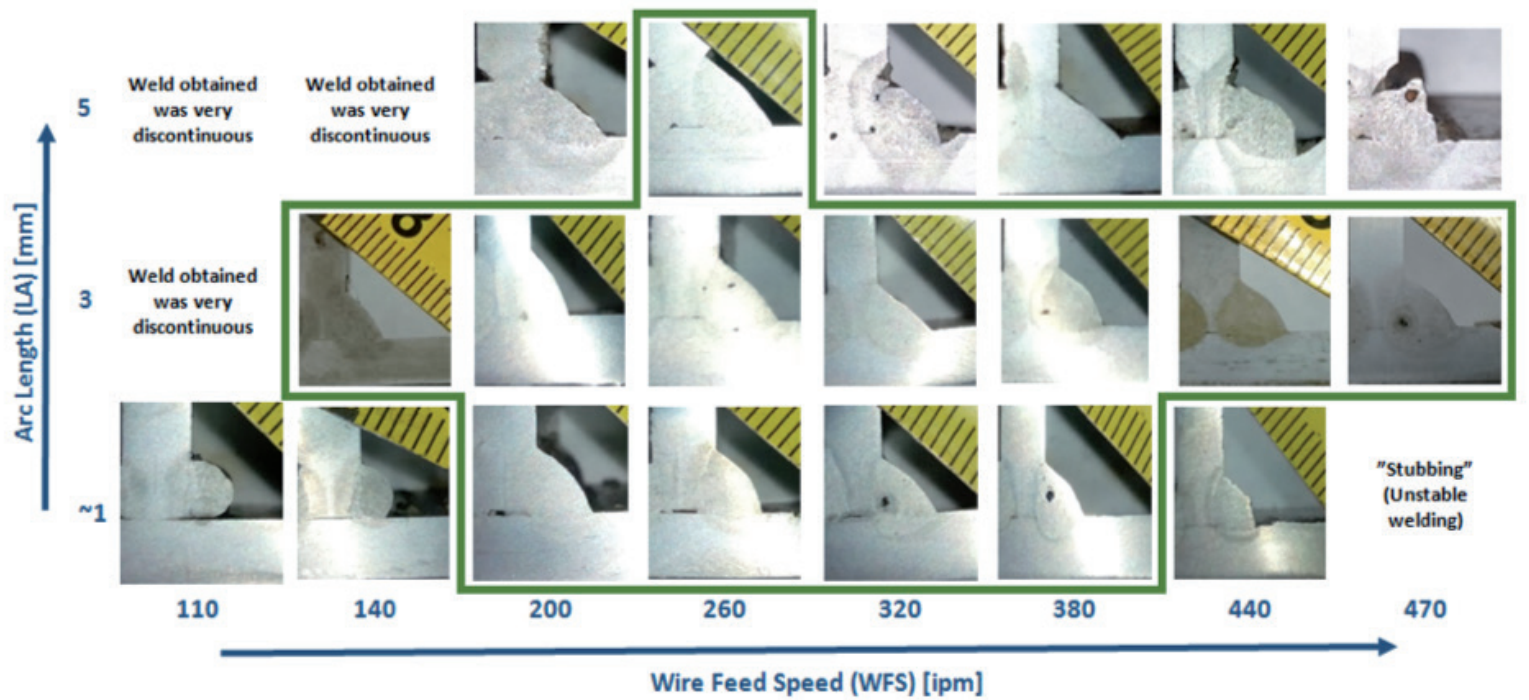

The shaded area of both graphs would be the productivity window and represents the set of combinations of welding parameters that would make it possible to obtain during the production welds according to the design (fillets with leg -4 $\mathrm{mm}$ in $2 \mathrm{~F}$ position), using the $F C A W$ process with an electrode class E71T-11, Ø0.035 " (Ø0.9 mm), which meet the pre-established acceptance criteria.

Welds outside this window would not meet the required quality level, either with respect to their dimensions or contain of defects.

Fig. 10. Voltage vs. WFS graph and productivity window for the application of this study

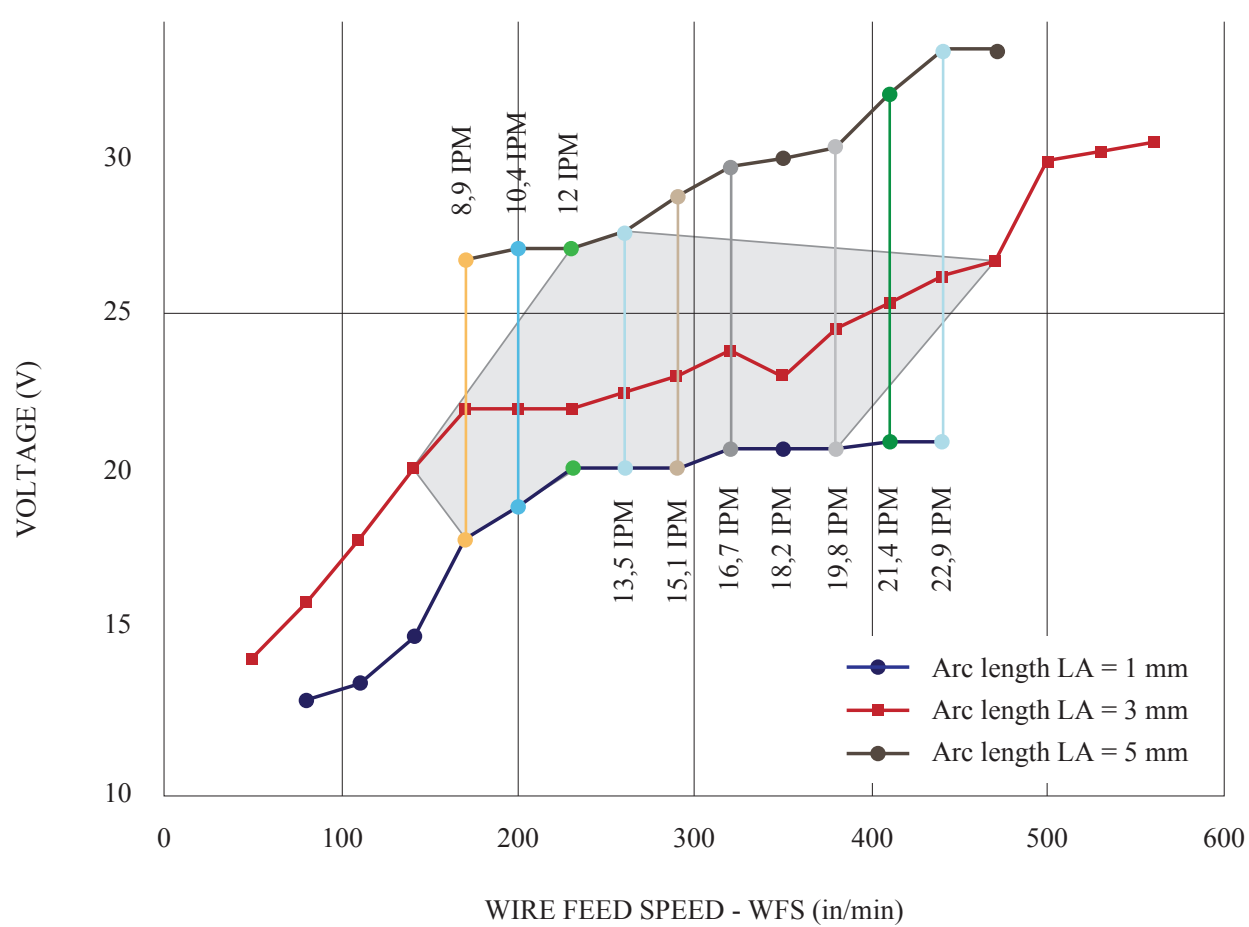


Fig. 11. Voltage vs. Current graph and productivity window for the application of this study

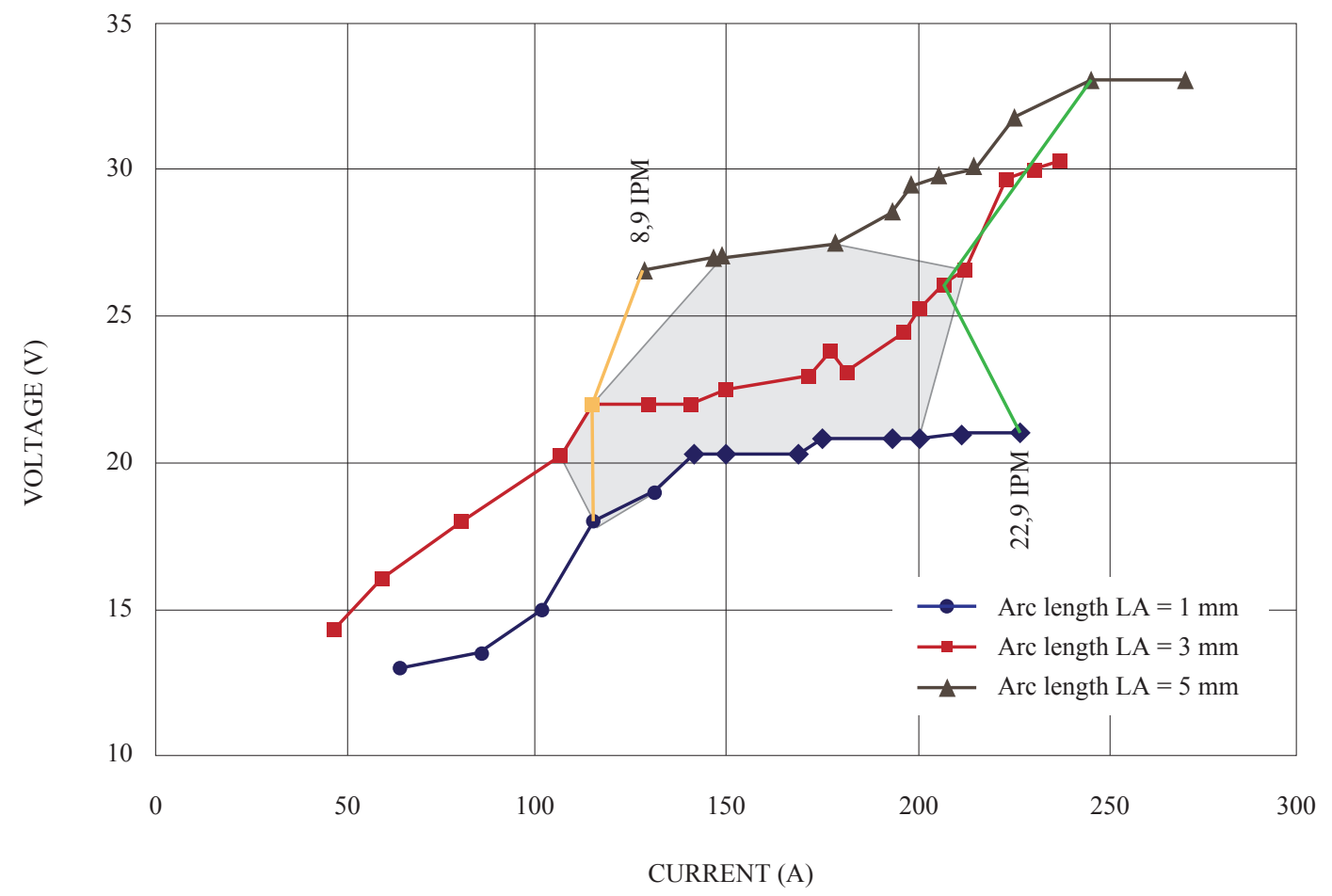

The graphs and productivity windows built within the scope of this study with the FCAW process are limited by zones where the levels of welding parameters (WFS, amperage and voltage) are too low to achieve penetration, root fusion and appropriate sizes and shapes of the fillet welds, and by zones with very high levels of welding parameters (Voltage and WFS) that produce unacceptable undercuts.

Through the construction of this kind of graphs the selection of welding parameters for a specific application is facilitated as they allow suitable voltages and amperages or WFSs to be found without having to use the iterative trial and error strategy that is more complicated to use and, very often, results in delays and frustration, and also can be avoided the use of parameters from books that do not take into account the specific weld required. The big number of welding parameters that allow to obtain a fillet weld with a leg size -4 $\mathrm{mm}$ is highlighted, which, from the perspective of the angular distortions of panels illustrated in Fig. 3 , would have a weight of electrode consumed per unit of length $W=0.785 \mathrm{~g} / \mathrm{cm}$ calculated through Equation 2:

$$
W=\left(\frac{S_{W}^{2}}{2}\right) * \frac{\rho}{\eta_{d}}
$$

Where $S_{w}$ is the leg size of the fillet weld $(0.4 \mathrm{~cm})$, $\rho$ is the steel density $\left(7.85 \mathrm{~g} / \mathrm{cm}^{3}\right)$ and $\eta d$ is the process efficiency (0.8). With this value for $W$ we are able to use Fig. 3 and plot the dotted red curve which is for a fillet close to $5 \mathrm{~mm}$ and see that the angular distortion for a plate with $T=6 \mathrm{~mm}$ can be around 10 radians (about $0.6^{\circ}$ ) or less.

As a complement to the Voltage vs. WFS and Voltage vs. Current graphs, it is also very useful in semi-automatic processes, such as the FCAW or $G M A W$, to have the relationship between the current and the WFS, which is also constructed collaterally with the ARCWISE strategy without other tests. Fig. 12 shows the relation of Current vs. WFS that allows the conversion of the arc current (which is normally a parameter of interest in welding) into wire feed speed which is the parameter that is adjusted in the GMAWIFCAW welding equipment. 
Fig. 12. Graphic with the Current relationship VS WFS

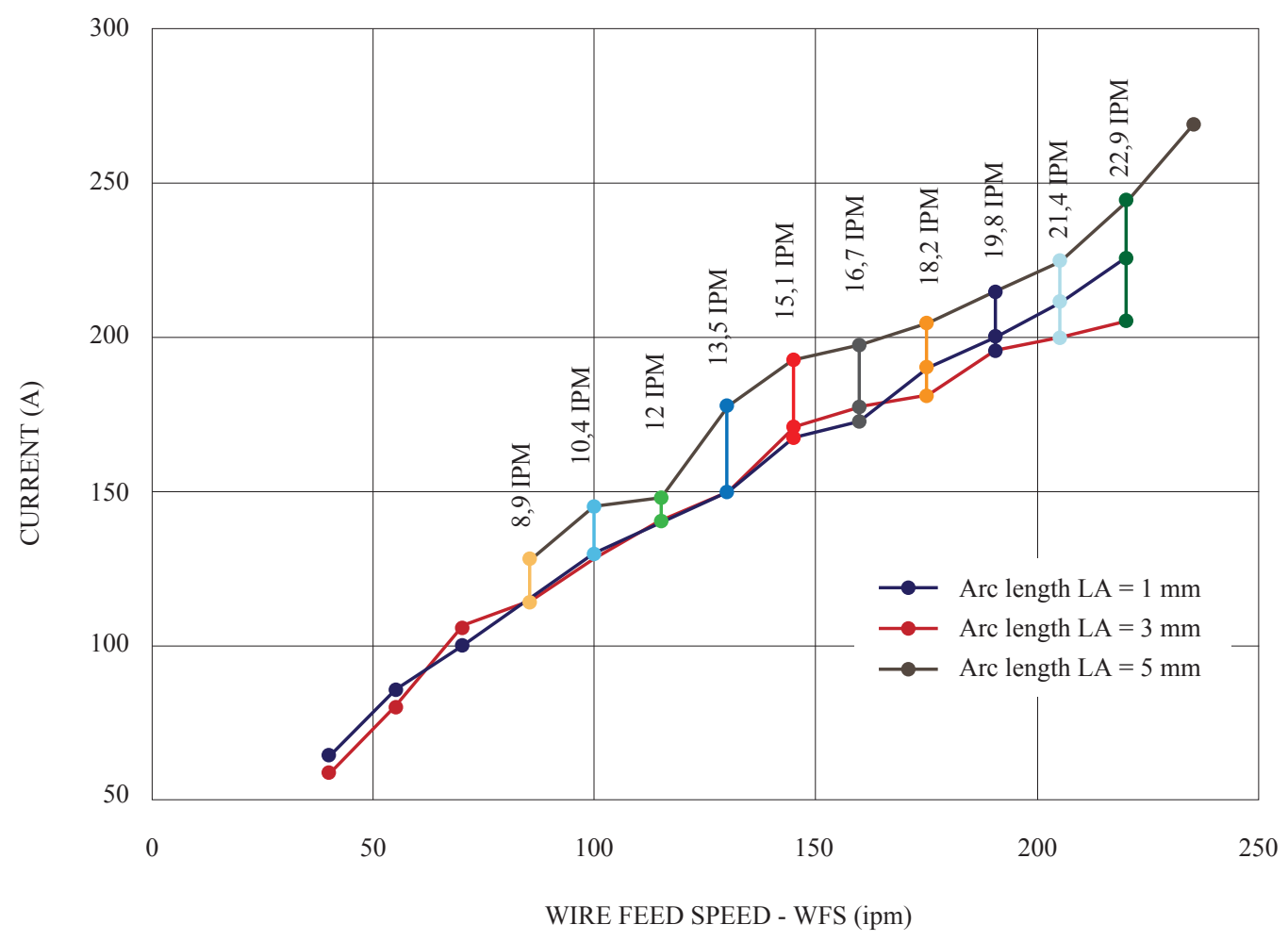

Finally, in order to show that the databases that are possible to build applying the ARCWISE method can be very diverse, the productivity window drawn on the graph of the relation of the Heat Input vs. WFS is included as an example in Fig. 13. The heat input $(\mathrm{HI})$ is calculated by Equation 3:

$$
H I=\frac{\left(V^{*} I\right)}{T S}
$$

It shows that the heat input is kept almost constant for each arc length independently of the WFS employed. The HIs associated with arc lengths $L A \approx 1 \mathrm{~mm}$ and $L A \approx 3 \mathrm{~mm}$ have very similar levels and its averages are $13 \mathrm{~kJ} / \mathrm{in}(330 \mathrm{~kJ} /$ $\mathrm{mm})$ and $15 \mathrm{~kJ} / \mathrm{in}(385 \mathrm{~kJ} / \mathrm{mm})$, respectively. With these average HI values the approximate fillet size $W$ that could be obtained can be estimated by the following empirical relationship proposed by Miller (Miller, 2001):

$$
W=\sqrt{\frac{H I}{500}}
$$

Where $W$ represents the fillet leg size in inches and $\mathrm{HI}$ is the heat input in $\mathrm{kJ} / \mathrm{in}$. Therefore, with a HI between 13 and $15 \mathrm{~kJ} / \mathrm{in}$, there would be fillet sizes between 4.1 and $4.4 \mathrm{~mm}$, which are the same order of magnitude of the application, but a little larger than those obtained in the study.

With the window shown in Fig. 13, it is possible select suitable welding parameters to make the weld defined in our application modifying, for example, the WFS in order to increase productivity when the deposition rate goes up, without this change implying, necessarily, a significant elevation of the heat input that results in greater distortions.

Other graphics of interest that can be built for production based on the experimental ARCWISE strategy could be: Heat input vs. Deposition rate, Area of molten metal vs. WFS or TS, Dilution \% vs. WFS, Current or TS, among others. There are multiple possibilities. 
Fig. 13. Graphic with the relationship of the power input vs. WFS and the productivity window for the application studied

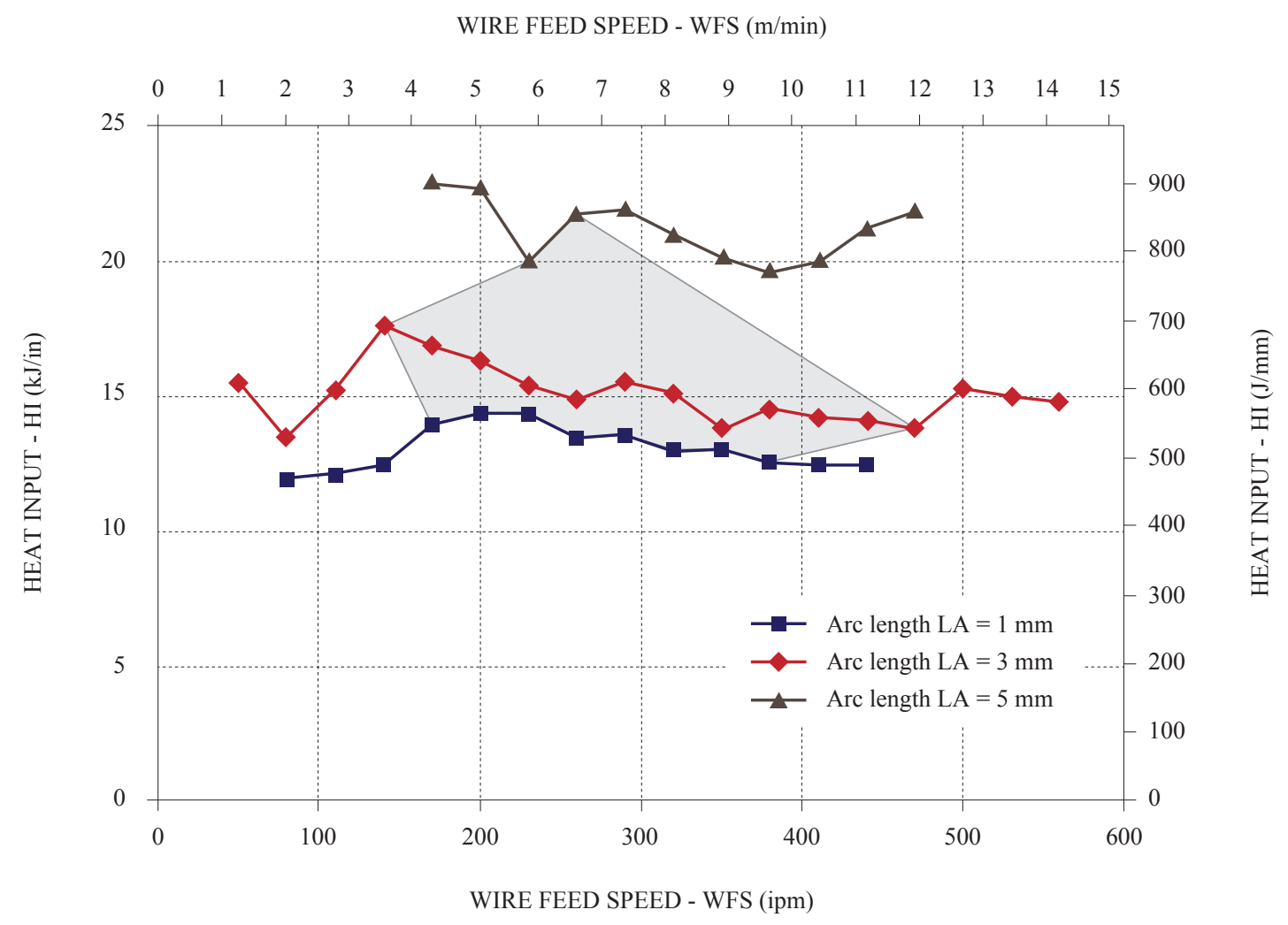

\section{Conclusions and future studies}

It has been shown how use the ARCWISE method for the building of productivity windows which can be used as engineering tools to facilitate the selection of welding parameters during the design of a WPS in order to achieve a specific application which meets a particular design combined with a set of acceptance criteria. The graphs cover a wide spectrum of parameters for a welding process in relation to WFS, current, voltage and welding speed, required to obtain a specific weld or application, clearly differentiating the combinations of adequate parameters from those that are inadequate. The ARCWISE methodology can be very useful when it is necessary to build a database with welding parameters to obtain small weld sizes that reduce the level of distortions in thin panels such as those used in the manufacture of midsize and small ships. The construction of the windows does not require sophisticated tools, equipment or tests and can be achieved with a relatively low number of testing welds.

\section{Proposal for future jobs}

A job such as that presented in this paper can be the base for a panoramic project of a thin-panel construction company that covers the numerous applications of production resulting from combining different weld sizes, plate thicknesses, positions, welding processes (GMAW, FCAW, SAW, etc.) and electrode classifications and diameters. If is desired, the project could be focused on the application of small fillet welds (3 $\mathrm{mm}$ or even less) for the manufacture of thin panels with plates 4 or $5 \mathrm{~mm}$ thick for ship components such as shells, decks, bulkheads, among others. 


\section{Acknowledgment}

The authors of this paper express their acknowledgments to the Universidad Nacional de Colombia, Medellín campus, and especially to the Welding Group and the Welding Laboratory of that campus for its support, financing and infrastructure, which enabled the development of this project.

\section{Bibliography}

ABS. (2016). Rules for materials and welding. American Bureau of Shiping. Estados Unidos.

ABS. (2018). Guide for nondestructive inspection of hull welds. American Bureau of Shiping. Estados Unidos.

AISI/AWS D3.7. (2004). Guide for aluminum hull welding. American welding society AWS.

ANSI/AWS D3.5:93R. (1993). Guide for Steel Hull Welding. Estados Unidos: American Welding Society, AWS.

AWS. (2010). Control costs by avoiding overwelding. American Welding Society. Welding Journal, diciembre de 2010.

BLODGETT, O. W. (1966). Design of Welded Structures. En O. W. Blodgett, Design of Welded Structures (pág. 6.4). Cleveland, Ohio: James F. Lincoln Arc Welding.
BOEKHOLT, R. (2011). Welding mechanization and automation in shipbuilding worldwide. En R. Boekholt, Welding mechanization and automation in shipbuilding worldwide (págs. 21,23). Cambridge: Abington Publishing/ Woodhead Publishing.

HARWIG, D. D. (2000). A wise method for assessing arc welding performance and quality. Welding Journal, 36-39.

IACS. (2012). No. 47 Shipbuilding and Repair Quality Standard. International Association of Classification Societies.

KOU, SINDO. (2002). Welding Metallurgy. John Whiley \& Sons. New Jersey, Estados Unidos.

MASUBUCHI, K. (1980). Analysis of welded structures. Pergamon Press.

MILLER, D. K., FUNDERBURK, S. (2001). Tools for reviewing welding procedures. Welding Journal, Julio de 2001, 40-43, Estados Unidos.

MILlER, D. K. (2006). Steel Design Guide Welded Connections. Estados Unidos, American Institute of Steel Construction.

TSAI, C.L., PARK, S. P. (Mayo de 1999). Welding distortion of a Thin-plate Panel Structure. Welding Journal, American Welding Society. 